\title{
RECOVERY OF HUMAN DIGINITY; KANTIAN CONSIDERATION
}

\author{
Chinedu Ifeakor ${ }^{1}$, Anselm Ikenna Odo ${ }^{2}$ \\ ${ }^{1,2}$ Department of Philosophy Nnamdi Azikiwe University, Awka, Nigeria. ${ }^{1,3}$ Department of Educational \\ Foundations Philosophy of Education Unit Nasarawa State University, Keffi, Awka, Nigeria. \\ cs.ifeakor@uniz.edu.ng ${ }^{1}$, anselmikenna4us@gmail.com ${ }^{2}$
}

\begin{abstract}
This paper tends to recover the dignity of human person using Kant's view point. Human dignity has for long being in a state of pang. It has been in the lowest esteem in the contemporary society; human right abuses, depersonalization of man, and lack of human respect. The researchers adopt expository method in carrying out the work. The researchers conclude that human life is a phenomenon characterized by a high sense of uniqueness. Every human person ought to be properly treated with such uniqueness, bearing in mind that- all are one and the same people.
\end{abstract}

Keywords: Recovery, human person and dignity.

\section{INTRODUCTION}

It is a noticeable event that human dignity has for long being in a state of pang. Obviously, many actions have been done to recover the Human dignity which has been in the lowest esteem in the contemporary society; human rights abuses, depersonalization of man, and lack of human respect, etcetera. Concurrently, there has been deep concern over the years about the dignity of human person by many philosophers and moralist. Immanuel Kant is indeed notable in this campaign for the recognition of the human person (Surzyn 2013). Base on his recognition, human life is a phenomenon characterized by a high sense of uniqueness. Every human person ought to be properly treated with such uniqueness, bearing in mind that all are one and the same people. Further, the institutions and conventions of society are designed as necessary conditions for the realization of authentic Human dignity and personhood. Despite this societal and institutional structure, there is still tension and conflict among persons living in the society owing to a lot of factors. Human rights abuses, arises out of those inevitable result of tension and conflict in the social dynamics and interaction of man.

The apparent display and unbridled quest for personal pleasure, interest and satisfaction has left some persons' victims in the manner of exploitation and debasement. The reality of abuses of human dignity and personhood is not a fairytale as its manifestation is exponentially increasing. Such can be seen in the acts of abortion, childtrafficking, gay marriages, cloning, etc. the fundamental implication of these actions is that of making man a means to an end which apparently stands in stark contrast with the "manas-an-end" aphorism of Kant's Ethics. Unfortunately, spiritual and moral values are being neglected to a considerable degree, and materialism in its various shades tends to unmake man. If man is to lord it over nature as the creator commanded him and as the philosopher Francis Bacon and some other philosophers reiterated, then he should not lord it over nature in such a way that he becomes a slave to it; otherwise it would become vice versa.

More so, ethics is hardly playing its part in the society because the society has come to identify rights as the interest of the strong (Nwoye 2018; Besong 2019). For example, some follows the Machiavellian principle which opines that 'might is right'. It has also come to embrace cultural relativism as true. In this sense, it holds that moral and 


\section{Jumal Sosialisasi \\ Jurnal Hasil Pemikiran, Penelitian, dan Pengembangan \\ Keilmuan Sosiologi Pendidikan \\ Vol 8, Nomor 1, Maret 2021}

ethical standards of different cultural settings determine what are acceptable as good. But an ethical agent should know that more fundamentally true, is the fact that it is the right that informs mores and not the other way round. Other factors that have militated against ethics are personal relativism, individualism and the rising to prominence of existentialism and logical positivism. People now see themselves as reference points and one determinant of the good and the bad (Okpo 2020). They have become individualistic to the point whereby no one feels there is need for the moral sense of duty to interfere in the misconduct of other people.

\section{CLASSIFICATION OF KEY CONCEPTS}

\section{Recovery}

Recovery is the act or process of regaining or repossession of something lost. To recovery is to gain back the loss of personal identity which might has resulted as negligence or other views. Recovery here entails a returning to the former status or position as a human person. For example, I have been neglected, looked down because I am no body in the political affairs. It is now my time to recover my loss identity and to retaliate to them that we all are human beings that deserves equal treatment.

\section{Human Person}

Human can be regarded as a species that belongs to Homo sapiens. On the other hand, Person can be regarded as a character or part, as in a play; a specific kind or manifestation of individual character, whether in real life, or in literary or dramatic representation; an assumed character (Ross \& Braine 2013). Therefore, in conjunction, human person can be viewed and understood as an absolute whole not just from the perspective of end sought, but also from its origin. It is worthy to note that it is no longer pleasant or satisfactory to end at the level of defining the human person merely in relation to reason. Although, a human being is one who has reason and not an animal from the myopic sense per se. But reason is one of the many sterling qualities that make up a human person respectively, such as the moral sense of an individual too.

However, different meanings have been given to the phrase 'Human person'. Oftentimes and most commonly, it is being use to refer to an original or better still, inborn nature of a being (human) that is characterized by intelligence. Hence the human person is the unifying concept which identifies man as man. In other words, the human person is a special form of that which is biologically inherited in man's category of existence (Thorne 2004). Thus, they could be different human sexuality, morphological make-up but the one nature of the human person ever remains. The human person is then taken to be a resultant of man's characteristic experiences in any and all of societies so far. Therefore, the characteristics of the human person are intrinsically lucid; a human person lives in a group with basic similar necessities and activities with an encapsulated and a well-defined personal relationship. In conclusion, the human person possesses the cognitive ability to recognize differences both between people close to him and likewise of his very own kind. Dignity

The word dignity is the English derivative of the Latin word 'dignete', these two different words from different roots, connotes one and the same thing, that is, the quality of being esteemed, worthy or honored (Bacin 2015). It could also be used to refer to high rank, office or position or a legal title of nobility (Merriam lexicon).

It will not be out of place therefore, to say that, a human person is invested with honor as it is implicit in the word dignity. He has a dignity over other creatures that are non-self-conscious, “...the lifeless or merely animal nature...” (Shell 2009, P. 64). 


\section{TYPES OF HUMAN DIGNITY}

Human dignity can be grouped thus: intrinsic, attributed, and inflorescent. Dignity is fundamentally a value term. All uses of the word refer to the worth, stature, or value of some entity. In ordinary usage, the entity at issue is a human being. To speak of human dignity, then, is to say something about the worth, stature, or value of a human being. The word can also be used to speak of the worth, stature, or value of a particular class of human beings, or the class of all human beings, as well as with respect to individuals. Generally speaking, however, the various uses of the word 'dignity' fall into one of these three categories.

Intrinsic dignity: is the worth, stature, or value that human beings have simply because they are human, not by virtue of any set of biological, psychological, social, economic, or political conditions, nor of the views of other persons, nor of any particular set of talents, skills, or powers. Intrinsic dignity is the value that human beings have simply by virtue of the fact that they are human (Thiel 2012).

Attributed dignity: is the worth, stature, or value that human beings confer upon others by acts of attribution. The act of conferring this value may be accomplished individually or communally, but it always involves a choice. Attributed dignity is therefore a created value (Munzarová 2011). It constitutes a conventional form of value. For instance, we attribute worth or value to those we consider to be dignitaries, those we admire, those who carry themselves in a particular way, or those who have certain talents, skills, or powers. We can even attribute worth or value to ourselves using the word this way. We use the word in this attributed way, for example, when we say that extreme poverty creates degrading and undignified living conditions.

Inflorescent dignity: is referred to the way people use the word to describe the worth or value of a process that is conducive to human excellence or to describe the worth or value of a state of affairs by which an individual human being expresses human excellence (Sulmasy 2013).

\section{CHALLENGES OF HUMAN DIGNITY}

In today's world, we are faced with a lot of controversies and challenges on human dignity. Thus; the challenges are not far from the human right. However, the researchers outlined some of the challenges facing human dignity.

Respect for dignity: relating it to bioethics; it is one of the major problem.

This is because it is manifested in recognition of the right of the patient or the "study-subject" to have full awareness of the intended treatment. According to the Article 6 (Consent) of the Universal Declaration on Bio-ethics and Human Rights: "Any preventive, diagnostic and therapeutic medical intervention is only to be carried out with the prior, free and informed consent of the person concerned, based on adequate information. The consent should where appropriate, be express and may be withdrawn by the person concerned at any time and for any reason without disadvantage or prejudice" (Bergel 2015, p. 78).

The patient has the right to medical care of good quality care, right to freedom of choice.

The patient has the right to accept or refuse appropriate medical treatment after getting information. He/she has the right of information. The doctor must fully inform the patient about his/her disease, about the methods of treatment, about the results of treatment and the possible risks of treatment (World Medical Association 2015). 
Jumal Sosialisasi

Jurnal Hasil Pemikiran, Penelitian, dan Pengembangan

Keilmuan Sosiologi Pendidiikan

Vol 8, Nomor 1, Maret 2021

\section{With regard to the problems of informed consent}

Human dignity and human rights, such questions often arise: How to behave in extreme situations? For example, when there is no time to get informed consent from the patient or in the case of patients without the capacity to consent, as well as in more serious situations, for instance, in the case of dying patients and palliative care, vegetative patients and finally, the specific situations are embryo and fetus. There is no common public opinion on these issues. It is obvious that the philosophical and ethical interpretation of their status and careful and caring attitude toward embryo and fetus is necessary.

\section{KANTIAN VIEW POINT IN REGAINING HUMAN DIGNITY End-In-Itself}

Kant's concept of 'end-in-itself' refers specifically to rational beings (Sasa 2019). Thus, only living beings stands the chance of being addressed as beings that are selfcontained of 'end-in-themselves', hence Kant's assertion is necessary at this point:...man and in general every rational being exist as an end in himself, not merely as a means for arbitrary use by this or that will: he must in all his actions whether they are directed to himself or to other rational beings, always be viewed at the same time as an end (Jones 2004, p. 57).

It is a truism that Kant often prefers to talk about 'rational being' rather than 'men', 'persons' or 'people'. Presumably of course he never came across any rational being other than men. Kant believes that an essential aspect of rationality is the ability to act in accordance with laws. And also, he believes that morality is reason in action. The fact that Kant insists on applying the moral law to the wider category of rational beings is not just a pieces of 'wearisome pedantry'. It rather brings out an essential aspect of his ethical theory, namely, that morality must be grounded in rationality alone, not on any other special characteristics of human nature which are irrelevant. Thus the moral law is applicable to dogs, stones, children etcetera, insofar as they can be regarded as endowed with rational will which unfortunately they do not possess.

Although, Kant's formula of the end-in-itself seems to offer an immediate solution to the question of what kind of 'end' is meant here. Nevertheless, it is necessary to clarify some different notions of 'end' with its various meanings and implications so as to pinpoint exactly the kind of 'end' Kant means when he uses the slogan "a person as an end".

An end may mean aim, purpose or objective. For example, my aim (the end I seek) is to succeed as a President of a country or as a priest. This meaning of end does not fit in with the idea of respect for persons as ends. To use it so would involve one in a category mistake. The above use of 'end' is something which can be desired and brought about, and if one speaks of desiring and bringing about persons, it seems unintelligible. It is a situation or state of affairs that can be desired and brought about. Little wonder Russell\& Pigden (2013, p. 39) asserts that; "a person cannot...be an end in this sense because it is not how he is linked with a situation which can be desired or brought about".

Further, the term 'end' can mean that which is desirable in itself. Comparing that which is never to the notion of respect for persons as ends, this second meaning of the term 'end' is nearer to it than the first one. The reason is that this one can be used to differentiate a thing which is desirable as a means from that desirable as an end. For instance, a student may regard the passing of his examination as something desirable as a means to his desirable end of acquiring knowledge but he may also regard the acquisition of knowledge as a means to further desirable end of acquiring wealth. We can thus have 
chains of means and ends, and where they stop we have an end-in-itself. To hold that persons are ends desirable in themselves, will also land one on another category mistake. Hence Downie ${ }^{6}$ posits that; "that which is desirable can necessarily be desired; all that logically can be desired are situations or states of affairs, but persons are not situations or states of affairs".

More so, an 'end' can be intended to mean that which is valuable in itself. This sense of 'end' is the same with that which is desirable in itself because in talking of the valuable in itself, one is not confined to situations or states of affairs. Something can be said to be valuable in itself both as a means and as an end; but another thing may be valuable merely as a means. It in line with the foregoing therefore that Theophanous (1994, p. 24) rightly stated:...to regard something as being valuable merely as a means is to regard it as valuable merely for what one can get of it. It is no more than useful. A valuable thing which is not merely a means is valuable in itself.

It is therefore, in this category that respect for persons best fit in. But this should not be taken to mean that persons cannot be made use of as means; as the above indicates, to say that persons are ends valuable in themselves, does not preclude the possibility that, they can also be valuable as means. What is rather intended is that they are not simply means to ends. Paulsen provides an example of the statement through which Kant stressed the need for respect for persons as absolute ends, when he clearly stated that:

Every man is to be respected as an absolute end in himself and it is a crime to the dignity that belongs to him as a human being to use him, as a mere means for some external purpose (Sensen 2011, p. 75).

Herein, Kant is again stressing the inviolability of the human person. He is not just a tool to be used to serve the interest of another. He is rather a being possessed of absolute value, which should never be used as a mere means to a subjective end. This idea has many implications for the social and interpersonal relationships that exist today in Nigeria and beyond. For instance, the relationship between husband and his wife, teacher and student, the master and his servant, the ruler and the ruled, parents and children and so on. The implication of Kant's idea would entail an overhauling of these relationships in the positive light of showing respect for the rights of individuals and persons involved. With this brief encapsulation of types of ends, the concept of "end-in-itself" as it is used in the notion of respect for persons becomes unequivocal.

\section{CONDITIONAL VIS A-VIS UNCONDITIONAL REGARDS FOR OTHERS}

A conditional regard of a person, as the name suggests, is contingent upon his meeting certain criteria of estimation in order to be accepted. An unconditional regard, on the other hand is opposed to it. It is not dependent on the evaluator's criteria of estimation. When the regard directed to a person is tied to some specific characteristics or behavior, then the regard is said to be conditional because it depends on an 'if' or 'ifs'. The person is positively evaluated or linked because of those specific things that he/she does or is capable of doing. Since the evaluation depends on those specific qualities, then by implication the person would not be accepted 'if' the victim does not possess or do those things. In contrast to the above, unconditional regard of a person is not dependent on any 'ifs'. Thus, Grisez and Shaw (1974, p. 632) states:

One is not prized for what he does but for his intrinsic value as a human being, furthermore, unconditional approval is effusive and expresses generalized good will, a positive feeling that exists without regard to the person's specific behavior. 


\section{Jumal Sosialisasi \\ Jurnal Hasil Pemikiran, Penelitian, dan Pengembangan \\ Keilmuan Sosiologi Pendidikan \\ Vol 8, Nomor 1, Maret 2021}

Both conditional and unconditional regard of others have moral, psychological and even social implications. It will not be proper for one to hold tenaciously to the view or the idea of negative aspects, for instance, the regard directed to an insincere friend may be negative; a person may portray an attitude of hatred towards his friend because of his insincerity. A person may then only be prepared to give his friend a positive regard 'if; he (the friend) makes effort to change for good. A friend will then only be given positive regard if he meets the friend's criterion of evaluation, specifically, if he changes sincerely. Such a friend may then realize that he was hated by his friend because of his insincerity. In this therefore, such a person will not but learn the simple act of being sincere in all his endeavors as the case may be.

Further, when talking about the realm of social and interpersonal relations, one cannot but realize the fact that unconditional regard of others is morally very (more) relevant. Although, conditional regard may be relevant too in most cases, better still if it falls within the line of the above conditional analysis. In matters of love, sympathy, friendship, togetherness, unconditional regard is to a greater extent relevant as compared to conditional. It is no longer a hidden fact that oftentimes, people engage in friendship and love because of some sterling qualities people may possess. In other words, if such people did not possess those qualities they will not be loved or reckoned with. Hence, one may love a person because of beauty and hate another, perhaps because of unattractiveness. Such a person who loves mainly from the point of view of beauty may be doing that just to satisfy his passion as the case may be. Thus, for such a person beauty has primacy over the intrinsic dignity of every human person. But this is morally wrong and need not be overemphasized. In all relationships, unconditional regard of other should always take precedence. It can only be on the contrary if and only if the conditional regard directed to people for the betterment of their lives or emancipation of human dignity in one way or the other, otherwise it should left out. Every individual person whether tall or short, black or white, no matter the status, possess in one way or the other, dignity in as much as they are rational beings. If love for one another is planted on specific qualities rather than the intrinsic dignity and integrity of all persons, then such, love for one another will be unnecessarily unstable. Little wonder Johann (1959, p. 32) holds that; "When love is interested, when the attraction is based on a motive of profit or need, it has no difficulty in finding words to justify it'".

Thus, the priority of each individual person should be on laying a good foundation of love for one another on the intrinsic dignity of every human person. In doing so, there will be no discrimination of love whatsoever. Therefore, each person should be loved not because of any specific quality, but because each person is a human being, possessed of dignity and absolute worth.

\section{Golden Rule}

In regaining our human dignity, we should apply the principle of golden rule enshrined by Kant. Golden rule, Kant meant that one should treat somebody as the way you want to be treated in return.

\section{CONCLUSION}

From the ongoing, we are meant to understand that human life is aphenomenon characterized by a high sense of uniqueness. Therefore, every human person ought to be properly treated with such uniqueness, bearing in mind that all are one and the same people. 
Jumal Sosiafisasi

Jurnal Hasil Pemikiran, Penelitian, dan Pengembangan

Keilmuan Sosiologi Pendidifikan

Vol 8, Nomor 1, Maret 2021

\section{REFERENCES}

Bacin, S. (2015). Kant's idea of human dignity: Between tradition and originality. KantStudien, 106(1), 97-106. https://doi.org/10.1515/kant-2015-0008

Bergel, S. D. (2015). Ten years of the Universal Declaration on Bioethics and Human Rights. Revista Bioética, 23(3), 446-455. http://www.scielo.br/scielo.php?pid=S198380422015000300446\&script=sci_arttex t\&tlng=en

Besong, E. N. (2019). Emerging Sexual Ethics and the Erosion of African Ethos. GNOSI: An Interdisciplinary Journal of Human Theory and Praxis, 2(1), 71-83.

Grisez, G., Shaw. R. (1974). Beyond the New morality. London University of Notre Dame press.

Johann, R.O. (1959). The Meaning of Love. Westminister, the new man press.

Jones, R. C. (2004). The moral significance of animal cognition. Palo Alto, California: Tanford University.

Kant I. (1785). Fundamental Principles of the Metaphysics of Morals (10 ed). Project Gutenber Gutenberg.

Munzarová, M. (2011). Human dignity and medical ethics. Casopis Lekaru Ceskych, $150(9), 499-501$.

Nwoye, L. (2018). Ethical Issues in Arms Technology. GNOSI: An Interdisciplinary Journal of Human Theory and Praxis, 1(1), 25-33.

Okpo, O. (2020). Nigeria's Traditional Virtue Ethics and Business: An Ibibio Virtue Ethics Approach to Business Ethics. GNOSI: An Interdisciplinary Journal of Human Theory and Praxis, 3(1), 16-31.

Ross, J. F., \& Braine, D. (1994). The Human Person. The Philosophical Quarterly, 44(177), 536. https://doi.org/10.2307/2220254

Russell, B., \& Pigden, C. R. (2013). Russell on ethics: Selections from the writings of Bertrand Russell. London: Routledge.

Sasa, M. S. (2019). An Appraisal of the Concept of Beauty in Immanuel Kant's Philosophy. GNOSI: An Interdisciplinary Journal of Human Theory and Praxis, 2(2), 87-97.

Sensen, O. (2011). Kant on human dignity (Vol. 166). Walter de Gruyter.

Shell, S. M. (2009). Kant and the limits of autonomy. Cambridge, MA: Harvard University Press.

Sulmasy, D. P. (2013). The varieties of human dignity: A logical and conceptual analysis. In Medicine, Health Care and Philosophy (Vol. 16, Issue 4, pp. 937-944). https://doi.org/10.1007/s11019-012-9400-1

Surzyn, J. (2013). Scotus' inspirations in Immanuel Kant's transcendentalism. Folia Philosophica, ENG 29, 63-81.

Theophanous, A. C. (1994). Understanding social justice: An Australian perspective. Elikia Books.

Thiel, M. J. (2012). Human dignity: Intrinsic or relative value? In Journal de Medecine Legale Droit Medical (Vol. 55, Issues 1-2, pp. 48-55).

Thorne, A. (2004). Putting the person into social identity. In Human Development (Vol. 47, Issue 6, pp. 361-365). https://doi.org/10.1159/000081038

World Medical Association, W. (2015). WMA Declaration of Lisbon on the Rights of the Patient. WMA Declaration, October 1981, 1-6. 